\title{
EĞİTIM SEKTÖRÜ MUHASEBE UYGULAMA SÜREÇLERİ: ÖZEL OKUL ÖRNEĞİ
}

\section{Seda ERDOĞAN}

Tokat Gaziosmanpaşa Üniversitesi, Sosyal Bilimler Enstitüsü, İşletme anabilim Dalı, MuhasebeFinansman Bilim Dalı Doktora Öğrencisi, erdoganades@gmail.com

\section{Doç. Dr. Mihriban COŞKUN ARSLAN}

Tokat Gaziosmanpaşa Üniversitesi, İktisadi İdari Bilimler Fakültesi, İşletme Bölümü, mihriban.arslan@gop.edu.tr 


\title{
EĞiTIM SEKTÖRÜ MUHASEBE UYGULAMA SÜREÇLERİ: ÖZEL OKUL ÖRNEĞí1
}

\section{ÖZET}

Türk Dil Kurumu'nun (TDK) güncel sözlükte yaptığı tanıma göre örgün eğitim, bireylerin çalışma hayatına başlamadan önce okul veya okul niteliğine sahip yerlerde, belli kurallara ve amaçlara göre, kişilerin bilgi açısından gelişimlerini sağlamak için düzenlenen eğitimdir. Aynı şekilde özel okul ise, mülkiyeti devlete ait olmayan yani kişiye ve özel bir kurulaşa ait olan alanlarda verilen eğitimdir. Çalışmanın amacı, eğitim işletmelerinin öncelikli ve özellikli durumları göz önünde bulundurularak muhasebe uygulama süreçlerinin araştırılmasıdır. Literatürde yapılan incelemeler neticesinde özel okullarda muhasebe uygulama sürecine ilişkin yeterli çalışma olmadığı ve yapılan çalışmaların ise öncelikli noktasının vergilendirme olduğu tespit edilmiştir. $\mathrm{Bu}$ sebeple; eğitim sektöründe muhasebe uygulama süreçlerinin açıklandığı bu çalışma literatüre katkı açısından önemlidir.

Anahtar Kelimler: Eğitim Sektörü, Özel Okul Muhasebesi, Özel Okullarda Vergilendirme

EDUCATION SECTOR ACCOUNTING APPLICATION PROCESSES: SPECIAL SCHOOL CASE

\begin{abstract}
According to the definition of the Türk Dil Kurumu (TDK) in the current dictionary, formal education is the training organized to provide the development of individuals in terms of knowledge according to certain rules and purposes in places that have the character of school or school before the beginning of their working life. In the same way, the private school is the education given to the people who are not owned by the state and that belong to a private institution. The aim of the study is to investigate the application process of accounting by taking into consideration the priority and special situation of educational enterprises. As a result of the studies conducted in the literature, it has been determined that there is not enough work in the accounting application process in private schools and the priority point of the studies is taxation. Therefore; This study, which explains the accounting application processes in the education sector, is important in terms of contributing to the literature.
\end{abstract}

Key Words: Education Sector, Private School Accounting, Taxation in Private Schools

${ }^{1} \mathrm{Bu}$ çalışma 19-21 Nisan 2019 tarihlerinde Ankara'da yapılan 3rd International Symposium on Innovative Approaches in Scientific Studies sempozyumunda sunulmuştur. Gerekli düzenlemeler yapıldıktan sonra makale formatına getirilmiştir. 


\section{GİRIŞ}

Özel eğitim kurumları yürütmüş oldukları faaliyetler dolayısıyla hizmet işletmesi kategorisinde yer almaktadır. Bu sebeple yürütmüş oldukları faaliyetlerin muhasebeleştirilmesinde hizmet üretim işletmelerindeki muhasebe akış sürecinin izlenmesi gerekmektedir.

1739 sayılı Milli Eğitim Temel Kanunu'na göre ilköğretim görmek her Türk vatandaşının hakkıdır. İlgili kanununun 18. Maddesine göre Türk eğitim sistemi örgün eğitim ve yaygın eğitim olmak üzere iki ana bölümden oluşur. Örgün eğitim okul öncesi eğitim, ilköğretim, ortaöğretim ve yükseköğretimi kapsamaktadır. Yaygın eğitim ise; örgün eğitim yanında veya dışında düzenlenen eğitim faaliyetlerinin tümünü kapsar. Yani örgün eğitim olanaklarından faydalanamamış olanlara, okulunu erken birakanlara veya mesleki anlamda daha iyi yerlere gelmek isteyenlere uygulanan eğitimdir (Milli Eğitim Kanunu, 1973: 5104).

Türkiye Cumhuriyeti uyruklu gerçek kişiler, özel hukuk tüzel kişileri veya özel hukuk hükümlerine göre yönetilen tüzel kişilerce ve yabancılar tarafindan açılan kurumlar özel öğretim kurumları olarak adlandırılmaktadır. Özel öğretim okulları özel okullar (İlköğretim, ortaöğretim), özel rehabilitasyon merkezleri, dönüşüm okulları, özel muhtelif kurslar (yabancı dil, bireysel danışmanlık, kişisel gelişim vb.), özel motorlu taşıt sürücü kursları, özel öğrenci barınma hizmeti veren kurumlar ve özel öğretim kurslarından oluşmaktadır (Özel Öğretim Kurumları Kanunu, 2007: 10015). Sayılan bu kurumların öğretime başlayabilmesi için kurum açma izni alması zorunludur. İzin almak için yapılacak başvurular ilgili milli eğitim müdürlüğüne yapılmaktadır. Kurum açma izin belgesi almayan kurumlar öğrenci kaydı yapamaz. Bu iznin verilmesi için gerekli şartlar 5580 sayılı kanunda belirtilmiştir. Sayılan kurumlar ve kurumlarda çalışan personelin denetimini Millî Eğitim Bakanlığı, kurumun özel yönetmeliğini dikkate alarak yapmaktadır. İlgili kanunun 12. Maddesine göre; kurumlar, faaliyetlerini sadece kazanç sağlamak için düzenleyemezler. Ancak, Türk millî eğitiminin amaçları doğrultusunda eğitimin kalitesini yükseltmek, gelişmelerine firsat ve imkân verecek yatırımlar ve hizmetler yapmak üzere gelir sağlayabilirler.

Özel okullar şahıs olarak gelir vergisi ve kurum olarak kurumlar vergisi ödemektedir. Kurumlar Vergisi Kanunu'na (KVK) göre, kurumların elde ettikleri kazanç ticari kazancı oluşturduğu için ticari kazanç usullülerine göre vergilendirilmektedirler. Ayrıca eğitim kurumları açısından hesap dönemi farklılık göstermektedir. Vergi Usul Kanunu'nun (VUK) 174. Maddesine göre hesap dönemi normal olarak takvim y1lıdır. Ancak yürüttükleri faaliyetler itibariyle bu takvim y1lı kendilerine uygun olmayanlar Maliye Bakanlı̆̆ı'na başvurarak 12'şer aylık özel hesap dönemleri belirleyebilmektedir (Vergi Usul Kanunu, 1961: 3514).

KVK madde 5/1-1'e göre okul öncesi eğitim, ilköğretim, özel eğitim ve orta öğretim özel okulları ilgili Bakanlığın görüşü alınmak suretiyle Maliye Bakanlığının belirleyeceği usuller çerçevesinde beş hesap dönemi itibarıyla elde edilen kazançlar kurumlar vergisinden istisnadır. $\mathrm{Bu}$ sayılan kurumların büfe, kantin, kafeterya, kitap satış yeri işletmelerinden veya kiraya verilmesinden doğan kazançlar istisna değildir. Ancak yemek ve konaklama hizmetleri eğer okul tarafindan verilir ve bu hizmet okul ücretine dâhil olursa yine istisna kapsamında değerlendirilecektir. Ayrıca yemek hizmetinin dışarıdan sağlanıyor olması istisna uygulanasına engel oluşturmayacaktır (Kurumlar Vergisi Kanunu, 2006: 9887). Gençyürek (2004) 'e göre bu istisnadan yararlanmak için özel öğretim kurumun 1.01.2004 tarihinden sonra faaliyete geçmiş olması ve Maliye Bakanlığı'na yazılı müracaat etmesi gerekmektedir. Bakanlık Millî Eğitim Bakanlığı'nın da görüşünü alarak konuyla ilgili görüşünü kurumun bağlı olduğu vergi dairesi başkanlığına bildirecektir (Aktaran; Öz ve Buyrukoğlu, 2011: 85).

Çalışmanın amacı, eğitim işletmelerinin öncelikli ve özellikli durumları göz önünde bulundurularak muhasebe uygulama süreçlerinin araştırılmasıdır. $\mathrm{Bu}$ çalışmada eğitim sektörü içerisinde önemli bir yeri olan özel okulların muhasebe uygulama süreçleri dönem başı işlemleri, dönem içi işlemleri ve dönem sonu işlemleri olmak üzere üç kısımda ele alınmıştır.

\section{MATERYAL YÖNTEM}

Çalışmada özel okulların muhasebe süreçleri literatür taranarak betimsel ve içerik analizi yapılmıştır. Uygulamada ele alınan özel okul vaka çalışması olarak kurgulanmıştır. Uygulamada ele alınan örnekler araştırmacıların detaylandırılması için oluşturulmuştur. Çalışmada kullanılan örnekler 
literatürde yapılmış çalışmalardan derlenerek tekrar hazırlanmıştır. Çalışmada ABC Özel Okulunun muhasebe uygulama sürecine yer verilmiştir. Okulun 2000 yılında faaliyete geçtiği varsayılmıştır.

\begin{tabular}{|c|l|r|r|}
\hline \multicolumn{1}{|c|}{01.07 .2018} & 17000,00 & \\
120 Alıcılar & & 15000,00 \\
120.01 .04 Öğrenci Ahmet & 2000,00 \\
380 Gelecek Aylara Ait Gelirler & \\
600 Yurtiçi Satışlar & \\
Yeni dönemde öğrenci kayıt işlemi & \\
\hline
\end{tabular}

Dolayısıyla kurumlar vergisi istisnasının dışında kalmaktadır. Okulun hesap dönemi 1 Temmuzda başlamakta, 30 Haziranda sona ermektedir. Yani okul kurumlar vergisi mükellefi ve özel hesap dönemi kullanmaktadır. $\mathrm{ABC}$ özel okulunun muhasebe süreci üç yöntem şeklinde ele alınmıştır. İlk olarak dönem başı işlemlerine yer verilmiştir. Bu aşamada okulun kayıt alma sürecine değinilmiştir. Kayıt sürecinde avans işlemleri ve eğitim indirimi muhasebe kayıtlarına yer verilmiştir. İkinci yöntem olarak $\mathrm{ABC}$ özel okulunun dönem içi muhasebe işlemlerine yer verilmiştir. Bu aşamada okulun, geçici vergi, personel giderlerini, ücretsiz öğrenci okutulması, durumlarına yer verilmiştir. Üçüncü yöntem olarak dönem sonu işlemlerine yer verilmiştir. Bu aşamada ise yansıtma kayıtlarına, gelir tablosu ile ilgili hesapların ilgili hesaba aktarılmasına, geçici vergi ve kurumlar vergisi ödenmesine ilişkin kayıtlara yer verilmiştir.

\subsection{Dönem Başı İşlemleri}

Bu başlık altında özel okullarda öğrenci kaydının alınması ve eğitim indirimi uygulanmasına yönelik işlemlere yer verilmiş̧ir. Kayıt alma işlemlerinde dikkat edilmesi gereken konular; eğitim öğretim dönemi, sonraki eğitim dönemi için alınan avanslar ve taksitlendirme işlemleridir. Eğitim indirimi uygulamalarına yönelik olarak eğitim ücretinin peşin ödenmesi, erken kayıt yapılması, öğrenci velisinin de aynı okulda eğitim görmüş olması, okul personelinin çocuğu olması, iki ya da daha fazla kardeşin aynı okulda eğitim görüyor olması, öğrencinin hem ilköğretimde hem de orta öğretimde aynı okula devam etmesi durumlarına örnek verilebilir.

Örnek 1-2'de öğrencilerin eğitim kurumuna kaydedilmesi işlemlerine değinilmiştir. Bu amaçla sonraki eğitim döneminde de aynı okula devam etmek isteyen öğrenciden avans alınması ve erken kayıt durumunda işletmenin uygulayacağı eğitim indirimi durumlanı incelenmiş ve bu işlemlerin muhasebeleştirilmesi sürecine yer verilmiştir.

Örnek 1: 2017-2018 Eğitim öğretim yılında 10. sınıfta olup, bir sonraki öğretim yılında da ABC Özel Okullarına devam etmek isteyen öğrenci Ahmet için 20 Haziran 2018 tarihinde eğitim ücretine istinaden $2.000 \mathrm{TL}$ kredi kartı ile tahsil edilmiştir. Öğrencinin 1 yıllık eğitim ücreti 17.000 TL'dir. Ayrıca öğrencinin velisi bu ücreti 5 eşit taksitle ödeyeceğini belirtmiştir. İlk taksit Temmuz ayında tahsil edilmiştir.

\begin{tabular}{|l|l|r|r|}
\hline 1 & \multicolumn{1}{|c|}{20.06 .2018} & 2000,00 & \\
& $\begin{array}{l}\text { 108 Diğer Hazır Değerler } \\
340 \text { Alınan Avanslar }\end{array}$ & \\
340.01 Ortaöğretim Öğrenci Avansları & & \\
Sonraki eğitim yılı için alınan ön kayıt avans1 & & \\
\hline
\end{tabular}


Eğitim Sektörü Muhasebe Uygulama Süreçleri: Özel Okul Örneği



Örnek 2: Y1llık eğitim ücreti 15.000 TL olan öğrenci Ayşe için 18.06.2018 tarihinde \%10 erken kayıt indirimi yapılmıştır. ABC Özel Okulları ile öğrenci velisi arasında yapılan anlaşma gereği ücretin 10 taksitte ödenmesi gerekmektedir. İlk taksit ödemesi 23.07.2018 tarihinde yapılmıştır. (Katma Değer Vergisi (KDV) \%8).

\begin{tabular}{|c|c|}
\hline Yıllık Eğitim Ücreti & 15.000 \\
\hline İndirim Tutarı $\left(1500^{*} 0,10\right)$ & 1.500 \\
\hline İndirim Sonrası Tutar & 13.500 \\
\hline Aylık Taksit Tutarı (13500/10) & 1.350 \\
\hline
\end{tabular}

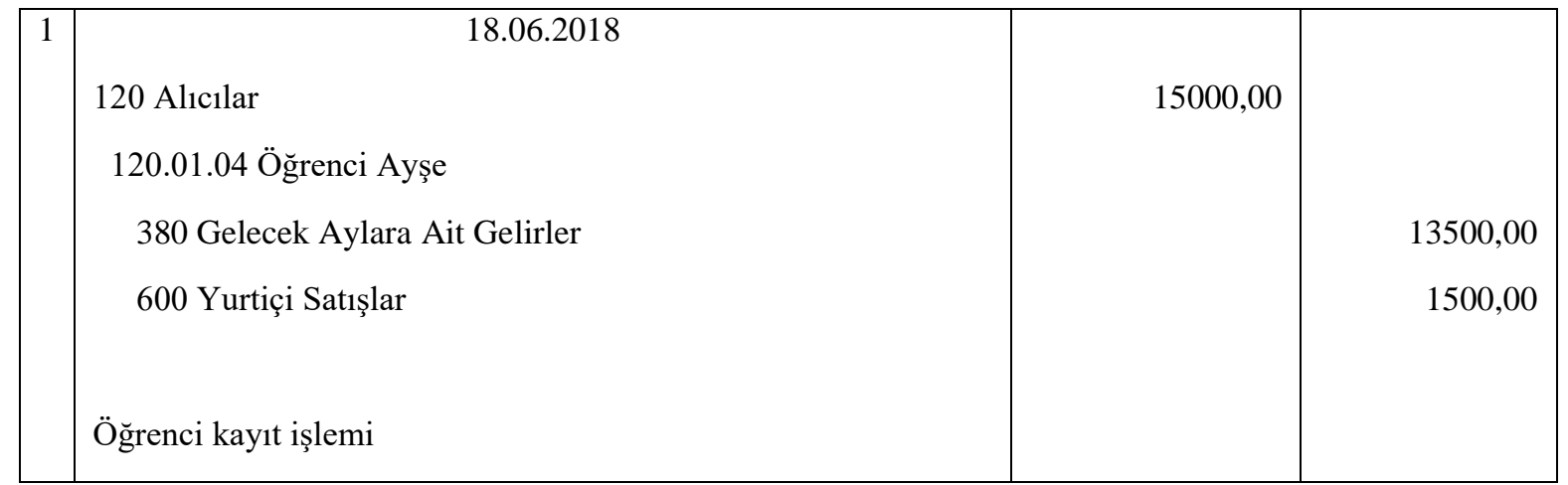




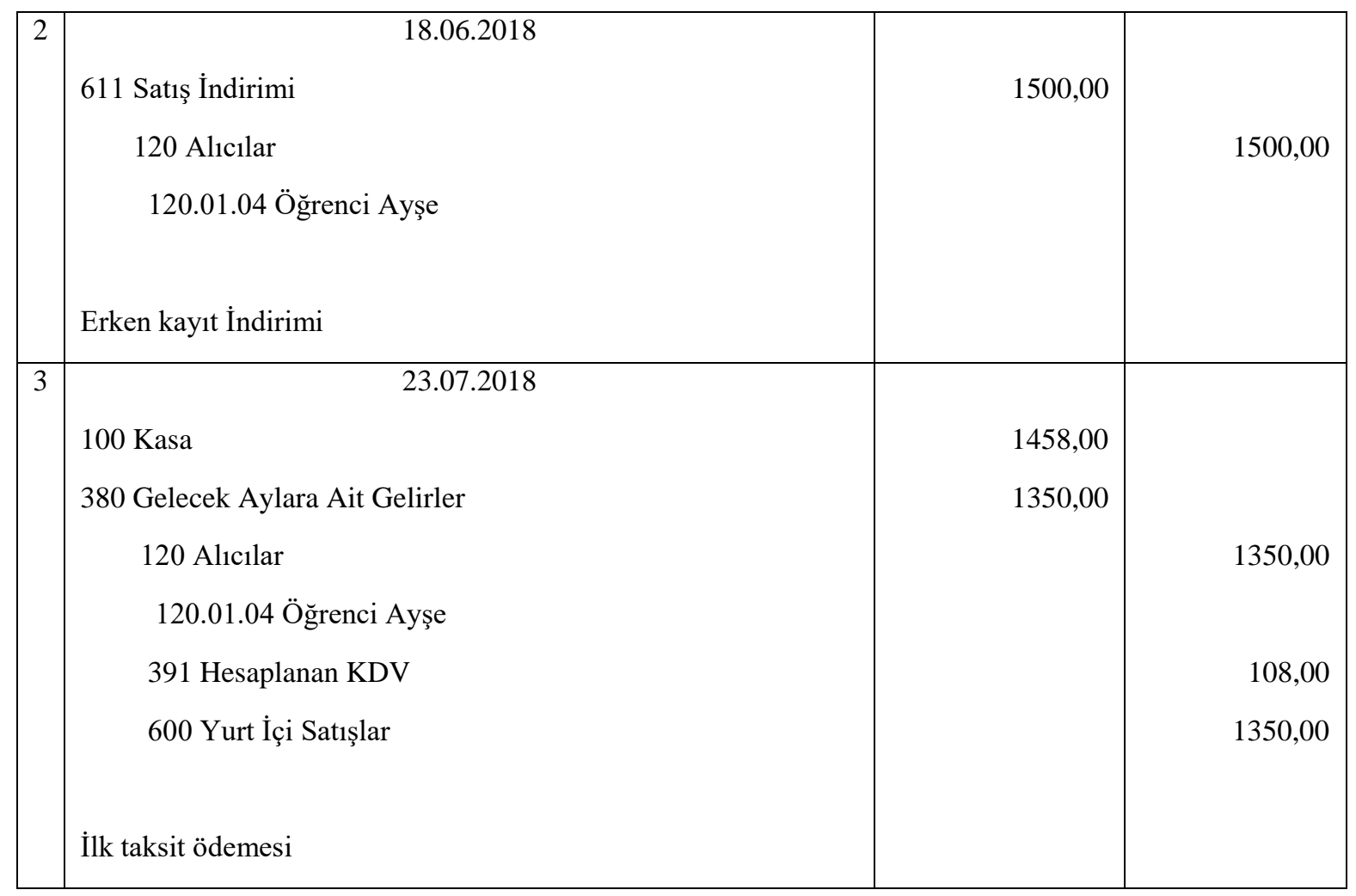

\subsection{Dönem İçi İşlemleri}

Bu bölümde özel okullarda bedelsiz öğrenci okutulması, geçici vergi ve personel ücretlerinin muhasebe işlemlerine yer verilmiştir.

İlk olarak özel okullarda bedelsiz okutulan öğrenciler için düzenlenen fatura ve vergi boyutu incelenmiştir. Eğitim sektöründe KDV oranı \%8'dir. Okul Servis Araçları Hizmet Yönetmeliği kapsamında verilen öğrenci taşıma servis hizmeti, dışarıdan veya okul bünyesinde sağlanmasına bakılmaksızın \%8 oranında katma değer vergisine tabidir. Servisin dışarıdan sağlanıyorsa, okulun servis hizmeti veren şirketten komisyon veya pay almasında durumunda KDV oranın \%18 olması gerekmektedir (Kabaca, 2016: 56). Eğitim işletmeleri, eğitim ücretlerini kayıt yapıldığı anda peşin olarak, taksitli olarak veya eğitim sonunda toplu bir şekilde tahsil edebilmektedir. Bu sebeple eğitim işletmelerinde KDV'yi doğuran olay tahsilatla ilişkili değildir. Nitekim Maliye Bakanlığı'nın yayınlamış olduğu 12.05.2010 tarihli eğitim kurumlarında ücretin taksitle alınması konulu özelgeye göre; "Eğitim hizmetinin aylık dönemler halinde bir öğretim y1lı için belirlenen hizmet bedelinin hizmetin ifa edileceği aylık sürelere bölünmesi suretiyle tespiti mümkün bulunmaktadır."(213 Sayılı Vergi Usul Kanunu İç Genelgesi, 2010).

Özel okullarda bedelsiz okutulan öğrencilerin KDV açısından bazı özellikli durumları bulunmaktadır. Çalışmada bu konu kapasitenin \%10'na kadar bedelsiz okutulan öğrenciler, kapasitenin \%10'u aşan sayıda bedelsiz okutulan öğrenciler ve yönetmelik çerçevesi dişında bedelsiz okutulan öğrenciler olarak incelenmiştir. KDV (17/2-b) maddesinde; 08.02.2007 tarihli ve 5580 sayılı Kanun hükümlerine tabi özel okullarca bedelsiz verilen eğitim ve öğretim hizmetlerinde ilgili dönemdeki kapasitelerinin (\% 10) 'unu geçmemek üzere verilen bedelsiz eğitim ve öğretim hizmetlerinin KDV'den istisna olduğu hüküm altına alınmıştır. Buna göre bir özel okul kapasitesinin \%10'unu aşmayan sayıda burslu ve ücretsiz olarak bedelsiz okuttuğu öğrencilere vermiş olduğu hizmetler üzerinden düzenlediği faturalardan KDV tahsil etmeyecektir. Muhasebe kayıtları açısından özellikli olan durum hem indirilecek KDV hem de hesaplanan KDV uygulamalarındaki farklılıktır. Yukarıda bahsedildiği üzere indirilecek KDV'nin bedelsiz okutulan öğrenciler için yapilan harcamalardan indirilmesi ve iadesi mümkün değildir. Bu sebeple bedelsiz okutulan bu öğrencilerin okul tarafindan yüklenilen indirilecek KDV tutarının, "740 Hizmet Üretim Maliyeti” hesabında izlenmesi gerekecektir. İndirim konusu yapılamayan bu KDV'lerin toplamı dönem kazancının 
tespitinde gider olarak dikkate alınacaktır. Hesaplanan KDV açısında ise; ilgili dönem kapasitesinin \%10'una kadar bedelsiz okutulan öğrenciler için emsal bedel üzerinden fatura düzenlenecek, KDV hesaplanacak ancak, "KDV Kanunu'nun 17/2b maddesine göre KDV tahsil edilmemiştir" şerhi konulacaktır. Faturanın açıklama kısmına da "Ücretsiz/burslu okutulan öğrenci" yazılacaktır (Ateş, 2016: 613-614).

Örnek 3, 4 ve 5'te bedelsiz okutulan öğrencilerin kapasiteye göre ve istek dâhilinde okutulması durumlarının muhasebeleştirilmesi işlemlerine yer verilmiştir.

Örnek 3: ABC Özel Okulları'nın 3 Ocak 2018 dönemine ait kapasitesi 1.000 öğrencidir ve 50 öğrenci bedelsiz okutulmaktadır. Ayrıca 3 Ocak 2018 dönemine ait yüklenilen toplam KDV 250.000 TL'dir.

\begin{tabular}{|c|c|}
\hline Yüklenilen KDV & 250.000 \\
\hline Vergiye Tabi Öğrenci & 950 \\
\hline Bedelsiz Okutulan Öğrenci & 50 \\
\hline Toplam & 1000 \\
\hline Bedelsiz Öğrenci Oranı & $\% 5(50 / 1000$ \\
\hline Gider Kaydedilmesi Gereken KDV & $12500(25000 * \% 5)$ \\
\hline
\end{tabular}

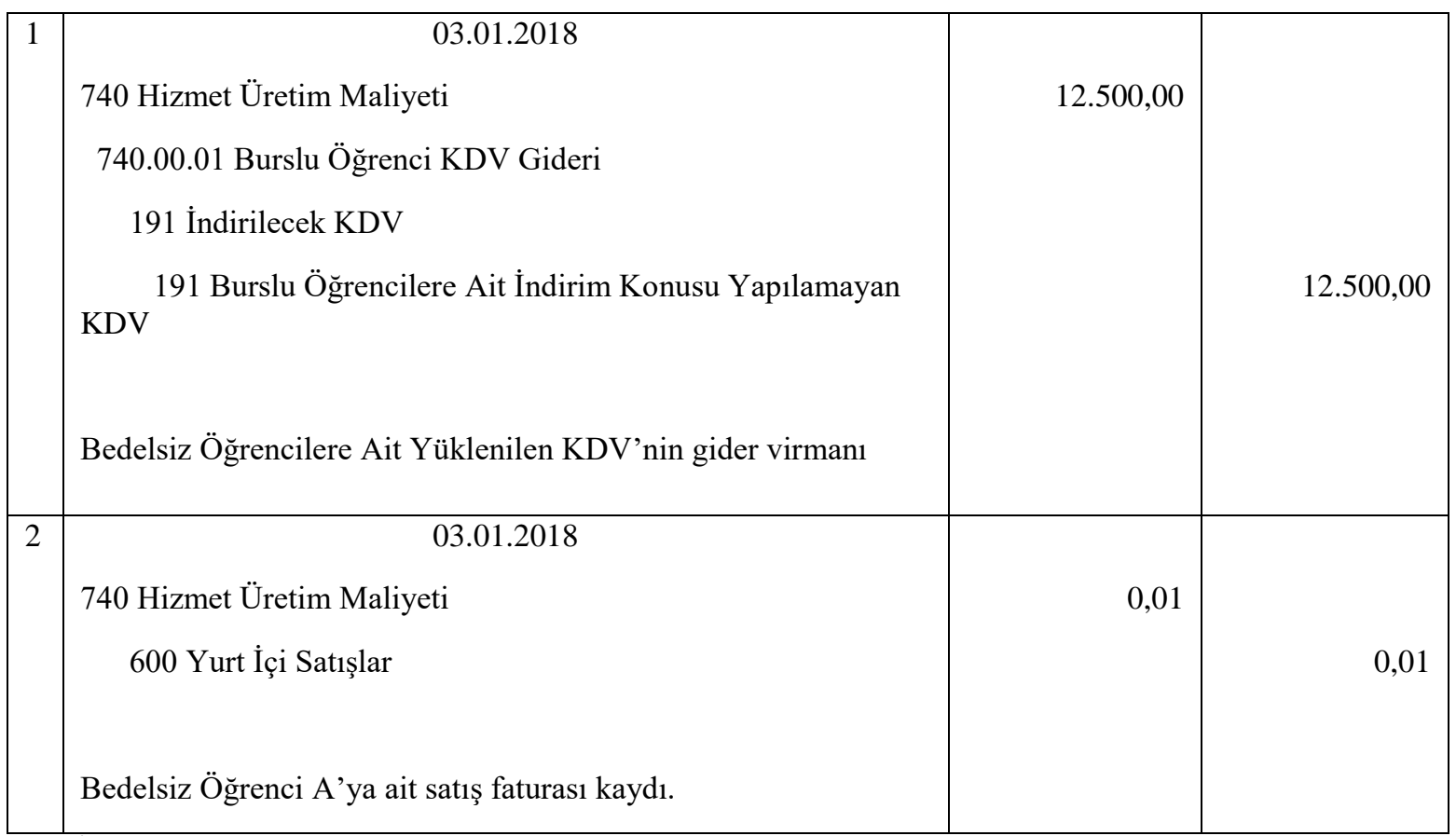

İndirilecek KDV açısından; ilgili dönem kapasitesinin \%10'unu aşan sayıda bedelsiz okutulan öğrenciler KDV Kanunu'nun 17/2b maddesine göre katma değer vergisinden istisna olmadığından, söz konusu öğrenciler için yapılan harcamalara ait KDV tutarları maliyet olarak değerlendirilmeyecek, indirim yoluyla giderilecektir. Hesaplanan KDV açısından; Kapasitenin \%10'unu aşan sayıda bedelsiz okutulan öğrenciler için emsal bedel üzerinden fatura düzenlenmesi gerekmektedir. Ayrıca öğrenci ücretlerinin tamamı üzerinden KDV hesaplanacaktır. Faturanın açıklama kısmına "Ücretsiz/burslu okutulan öğrenci” şerhi konulacaktır. Bu öğrenciler için hasılat kaydı yapılmasına gerek yoktur ancak fatura düzenleme gerekliliği nedeniyle, düzenlenen fatura ilgili hesaplara itibari değer ile kaydedilecektir. Tahsil edilmeyen tutarlar için hasılat kaydının yapılmasına gerek yoktur. Yine fatura düzenlenmesi gerekliliği nedeniyle, düzenlenen fatura kayıtlarına İtibari değer ile kaydedilecektir (Ateş, 2016: 613-614). 
Örnek 4: ABC Özel Okulları'nda 3 Nisan 2018 dönemine ait, kapasitenin \%10’unu aşan 45 bedelsiz öğrenci okutulmaktadır. Bedelsiz okutulan öğrencilere ilişkin emsal bedel üzerinden hesaplanan ücret tutar1 45.000 TL'dir. (KDV \% 8).

\begin{tabular}{|c|c|c|c|}
\hline 1 & 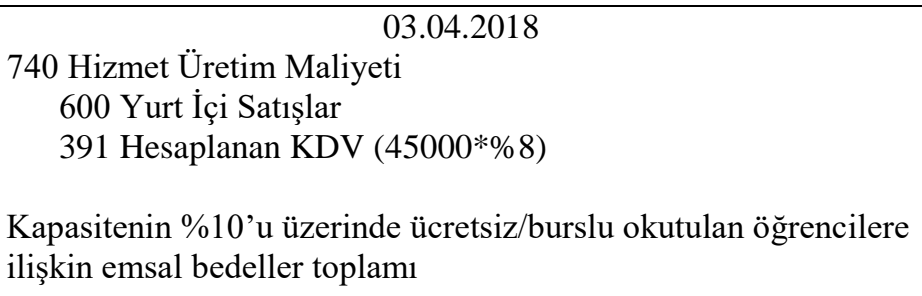 & 3600,01 & $\begin{array}{r}0,01 \\
3600,00\end{array}$ \\
\hline 2 & $\begin{array}{l}\qquad 03.04 .2018 \\
950 \text { Kanunen Kabul Edilmeyen Giderler } \\
\text { 951 Kanunen Kabul Edilmeyen Giderler } \\
\text { Tam ücretsiz okutulan öğrencilerin ücret tutarlarının KDV'sinin } \\
\text { KKEG olarak dikkate alınması }\end{array}$ & 3600,00 & 3600,00 \\
\hline 3 & $\begin{array}{l}\text { 30.06.2018 } \\
\text { 951 Kanunen Kabul Edilmeyen Giderler } \\
\text { 950 Kanunen Kabul Edilmeyen Giderler } \\
\text { Tam ücretsiz okutulan öğrencilerin ücret tutarlarının KDV’sinin } \\
\text { KKEG olarak dikkate alınması }\end{array}$ & 3600,00 & 3600,00 \\
\hline
\end{tabular}

Yönetmelik çerçevesi dışında bedelsiz okutulan öğrenciler ise; reklam amaçlı ve işletme sahibinin isteği üzerine okutulmaktadır.

Örnek 5: ACB özel okullarında kapasitenin \%10’unu aşan 5 öğrencinin başarılarında dolayı reklam amaçlı bedelsiz okutulmaktadır. Bu öğrencilere ilişkin emsal bedel üzerinden hesaplanan ücret 20.000 TL'dir. (KDV \%8). Aynı örneği işletme sahibinin isteği üzerine ücretsiz öğrenci okutulması durumu olarak da muhasebeleştiriniz.

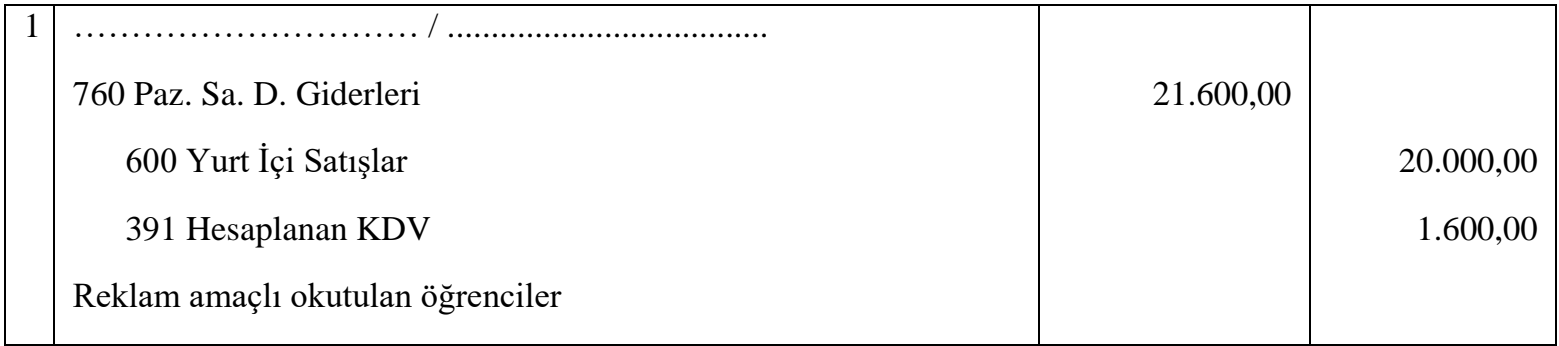

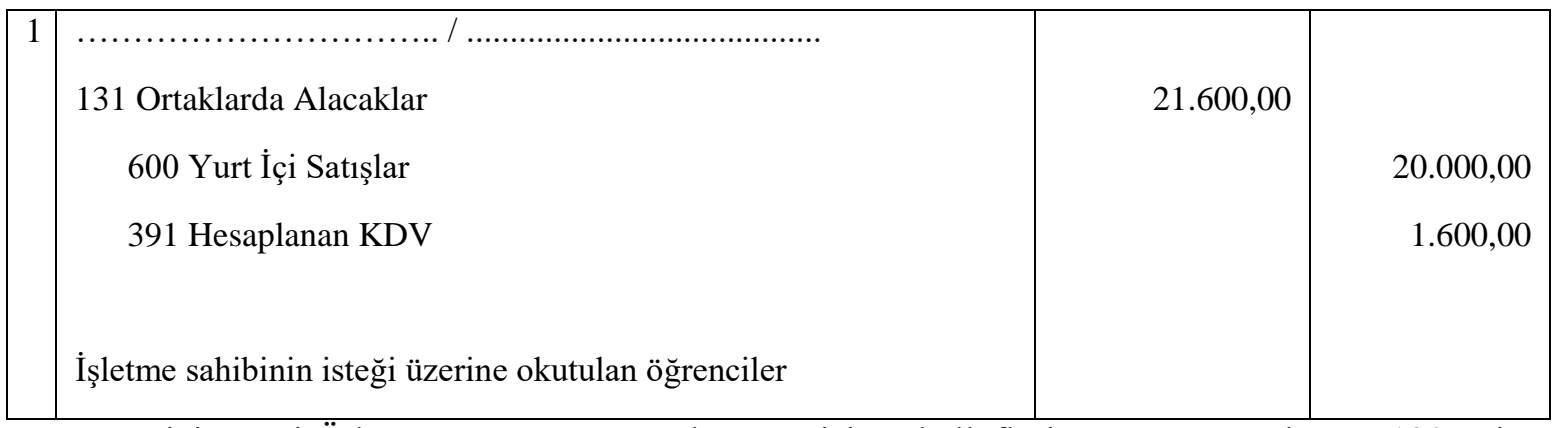

Geçici Vergi Ödene Durumu: Kurumlar Vergisi mükellefleri GVK'nun mükerrer 120'nci ve KVK'nun 32'nci maddeleri uyarınca geçici vergi ödemekle yükümlüdür. Geçici vergi dönemleri takvim yılının üçer aylık dilimleridir. Özel hesap dönemi kullanan mükelleflerin geçici vergi dönemleri, hesap dönemine göre değişim göstermektedir. ABC Özel Okulları Kurumlar vergisi mükellefi olduğu için geçici vergi ödemekle de yükümüdür. Okulun özel hesap dönemi olduğu için geçici vergi beyan ve ödeme tarihleri aşağıdaki tabloda belirtildiği gibidir. 
Eğitim Sektörü Muhasebe Uygulama Süreçleri: Özel Okul Örneği

\begin{tabular}{|c|c|c|}
\hline Vergilendirme Dönemleri & Beyan Zamanı & Ödeme Zamanı \\
\hline I. Dönem: Temmuz-Ağustos-Eylül & 14 Kasım & 17 Kasım \\
\hline II. Dönem: Ekim-Kasım-Aralık & 14 Şubat & 17 Şubat \\
\hline III. Dönem: Ocak-Ş̧ubat-Mart & 14 Mayıs & 17 Mayıs \\
\hline IV. Dönem: Nisan-Mayıs-Haziran & 14 Ağustos & 17 Ağustos \\
\hline
\end{tabular}

ABC Özel Okulu mizandan giderek gelir tablosunu hazırlamakta ve envanter çalışmalarını da çalışma kağıtlarında göstermektedir. Örnek 6'da özel okullarda geçici vergi hesaplaması ve muhasebeleştirilmesi işlemlerine yer verilmiştir.

Örnek 6: ABC Özel Okulları'nda 01.01.2018-30.03.2018 (3. Dönem Geçici Vergi) dönemine ait ticari kar1 5.780.000 TL'dir. Bu döneme ait 500.000 TL kanunen kabul edilmeyen gideri bulunmaktadır. Önceki dönemlerde ödenen geçici vergi tutarı 143.000 TL'dir ve dönem içinde kesinti yoluyla ödenen vergiler $24.000 \mathrm{TL}$ tutarındadır. Bu durumda ödenmesi gereken geçici vergi ve muhasebe kaydı aşağıda belirtildiği gibi olmalıdır.

\begin{tabular}{|c|c|}
\hline Ticari Karı $(+)$ & $\cdot 5.780 .000$ \\
\hline Kanunen Kabul Edilmeyen Giderler (+) & $\cdot \underline{500.000}$ \\
\hline Geçici Vergi Matrahı (=) & $\cdot 6.280 .000$ \\
\hline Hesaplanan Geçici Vergi (\%20) & $\cdot(1.256 .000)$ \\
\hline Önceki Dönemlerde Ödenen Geçici Vergi (-) & $\cdot(143.000)$ \\
\hline $\begin{array}{c}\text { Mahsup Edilecek Kesinti Yoluyla Ödenen Stopaj } \\
(-)\end{array}$ & $\cdot \underline{(24.000)}$ \\
\hline Ödenecek Geçici Vergi (=) & $\cdot 1.089 .000$ \\
\hline
\end{tabular}

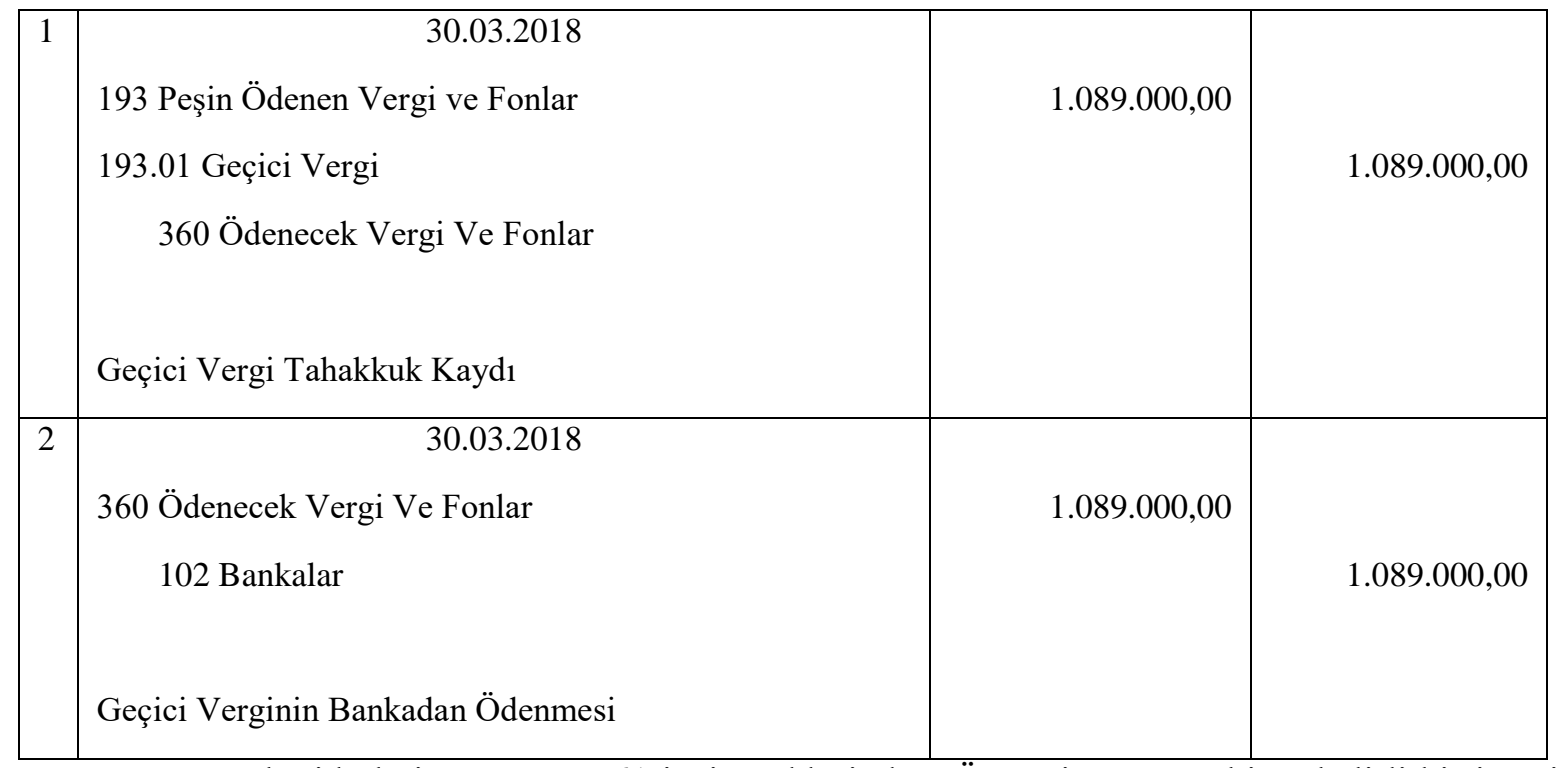

Personel Giderleri: GVK'nun 61 inci maddesinde; “Ücret, işverene tabi ve belirli bir işyerine bağlı olarak çalışanlara hizmet karşılığı verilen para ve ayınlar ile sağlanan ve para ile temsil edilebilen menfaatlerdir. Ücretin ödenek, tazminat, kasa tazminatı (mali sorumluluk tazminatı), tahsisat, zam, avans, aidat, huzur hakkı, prim, ikramiye, gider karşılığı veya başka adlar altında ödenmiş olması veya bir ortaklık münasebeti niteliğinde olmamak şartı ile kazancın belli bir yüzdesi 
şeklinde tayin edilmiş bulunması onun mahiyetini değiştirmez" denilmiştir (Gelir Vergisi Kanunu, 1960: 3374).

657 sayılı Devlet Memurları Kanunu'nun (DMK) ek 32. Maddesine göre; Eğitim ve Öğretim Hizmetleri Sınıfına dâhil öğretmen unvanlı kadrolarda görevli olup fiilen öğretmenlik yapanlara her öğretim yılında bir defaya mahsus olmak üzere ve eğitim öğretim yılının başladığı ay içinde Milli Eğitim Bakanı tarafından belirlenecek tarihte, Bakanlar Kurulu'nca belirlenecek miktarda öğretim y1lına hazırlık ödeneği ödenmektedir. Hazırlık ödeneği gelir vergisinden istisna tutulmuştur. Özel okul öğretmenlerine de öğretim yılına hazırlık ödeneği ödeneceği kararlaştırılmıştır. Özel okullarda ödenen bu ödeneğin dengi resmi okul öğretmenlerine ödenen tutar kadar olan kısmı gelir vergisine tabi değildir ancak resmi okullarda ödenen tutar asıldığı takdirde ilgili birimler, gelir vergisi kesintisi ve gerekli diğer kesintileri yapmakla yükümlüdür (Ağaya, 2012: 126). Maliye Bakanlığı'nın yayınladığı 2003/2 sayılı GVK iç genelgesine göre; Özel Öğretim Kurumlarında çalışan öğretmen ve personele ödenen eğitim-öğretim tazminatı ile yabancı dil tazminatı ve öğretim yılına hazırlık ödeneğinin resmi okul öğretmen ve personeline yapılan tutarı kadar kısmının gelir vergisinden istisna olduğu belirtilmiştir. Öğretim yılına hazırlık ödeneği yılda bir defa ve eğitim yılı başında verilmektedir. Bu tutar genellikle devletin belirlemiş olduğu tutardan fazla verilmektedir. Özel okullar bu fazla tutarı ikramiye adı altında ödemekte ve gerekli kesintilere tabi tutmaktadır. Eğitim-Öğretim tazminatı tutarının ise Bakanlar Kurulu tarafindan belirlenen ve gelir vergisinden istisna edilen miktar kadar olması gerekmektedir (Gelir Vergisi Kanunu İç Genelgesi, 2003).

Bütçe ve Mali Kontrol Genel Müdürlüğü’nün maaş istatistik verileri tablolarından yararlanılarak memur maaş katsayısı, sosyal güvenlik prim oranları, işsizlik sigortası prim oranları ve göstergeler kullanılarak personellere ait ücret ödemesi işlemleri muhasebeleştirilmiştir. Bakanlık ilgili oranları ve tutarları belli aralıklarla açıklamaktadır (BUMKO, 2019).

Örnek 7'de personele ödenecek eğitim tazminatı ve hazırlık ödeneğinin nasıl hesaplanması gerektiği ve muhasebeleştirilmesi gerektiğine dair bir uygulama yapılmıştır.

Örnek 7: ABC Özel Okulu'nda her ay düzenli olarak eğitim tazminatı ödemesi yapılmaktadır. 23 yıldır öğretmenlik yapan matematik öğretmeni Ayşe'nin brüt ücreti 4000 TL'dir. 2018 y1lı Bütçe Kanunu'nun K Cetvelinde "Diğer Ödemeler" başlığı altında yer alan bilgilere göre, 2018-2019 eğitim öğretim yılına ait öğretim yılına hazırlık ödeneği 1.130 TL'dir. ABC Özel Okullarında öğretim yılına hazırlık ödeneği olarak 1.880 TL ödenmesine karar verilmiştir. Eğitim-öğretim tazminatı ve hazırlık ödeneği tazminat tutarlarını muhasebeleştiriniz. (Yapılan işlemlerde 2019 yılı BUMKO verilerinden yararlanılmıştır.)

\begin{tabular}{|c|c|c|c|c|c|}
\hline Derece & Çalışma Yılı & Katsayı & MMK*9500 & Ĕ̆itim öğretim katsayısı & Ĕgitim öğretim tazminatı \\
\hline 2 & 23 & 0,108550 & 1031,23 & $\% 120,56$ & 1243,25 \\
\hline
\end{tabular}

\begin{tabular}{|l|r|}
\hline Brüt Ücret & 4.000 \\
\hline Eğitim Tazminatı & 1243,25 \\
\hline İşsizlik Sigortası Primi (\%1) & 40 \\
\hline SGK Primi (\%14) & 560 \\
\hline Damga Vergisi (binde 6) & 24 \\
\hline Gelir Vergisi Matrahı= Brüt Ücret - (Eğitim Tazminatı + SGK Primi + İşsizlik Sigortası Primi & $2.156,75$ \\
\hline Ödenecek Gelir Vergisi Toplamı (\%15) & 323,51 \\
\hline Net Ücret= Brüt Ücret - Kesintiler & $2.132,75$ \\
\hline SGK İşveren Payı (\%20,5) & 820 \\
\hline İşsizlik Sigortası İşveren Payı (\%2) & 80 \\
\hline Okul Tarafindan Karşlanacak Primler & 900 \\
\hline
\end{tabular}


Eğitim Sektörü Muhasebe Uygulama Süreçleri: Özel Okul Örneği

\begin{tabular}{|l|r|}
\hline Sosyal Yardım Toplamı & 1.880 \\
\hline Öğretim Ödeneği & 1.130 \\
\hline İkramiye & 750 \\
\hline İşsizlik Sigortası Primi (\%1) & 7,5 \\
\hline SGK Primi (\%14) & 105 \\
\hline Damga Vergisi (binde 6) & 11,28 \\
\hline Gelir Vergisi Matrahı= Brüt Ücret - (Eğitim Tazminatı + SGK Primi + İşsizlik Sigortası Primi & 637,5 \\
\hline Ödenecek Gelir Vergisi Toplamı (\%15) & 95,625 \\
\hline Net Ücret= Brüt Ücret - Kesintiler & $1.160,595$ \\
\hline SGK İşveren Payı (\%20,5) & 153,75 \\
\hline İşsizlik Sigortası İşveren Payı (\%2) & 15 \\
\hline
\end{tabular}

\begin{tabular}{|l|l|r|}
\hline 1 & \multicolumn{1}{|c|}{01.08 .2018} & $4.900,00$ \\
740 Hizmet Üretim Maliyeti & \\
740.01 Brüt Ücret & \\
740.02 SSK İşveren Payı & $3.052,49$ \\
740.03 İşsizlik Sigortası İşveren Payı & 347,51 \\
335 Personele Borçlar & $1.500,00$ \\
360 Ödenecek Vergi ve Fonlar & \\
360.01 Gelir Vergisi & \\
360.02 Damga Vergisi & \\
361 Ödenecek Sosyal Güvenlik Kesintileri & \\
361.01 SGK Primi (560+820)=1380 & & \\
361.02 İşveren Primi (40+80)=120 & & \\
Ayşe öğretmene eğitim tazminatı &
\end{tabular}




\begin{tabular}{|c|c|r|}
\hline \multicolumn{1}{|c|}{01.08 .2018} & $2.048,75$ \\
740 Hizmet Üretim Maliyeti & \\
740.01 Brüt Ücret (1.880) & $1.660,59$ \\
740.02 SSK İşveren Payı $(153,75)$ & 106,91 \\
740.03 İşsizlik Sigortası İşveren Payı (15) & \\
335 Personele Borçlar & \\
360 Ödenecek Vergi ve Fonlar & \\
360.01 Gelir Vergisi (95,625) & \\
360.02 Damga Vergisi $(11,28)$ & \\
361 Ödenecek Sosyal Güvenlik Kesintileri & \\
361.01 SGK Primi (105+153,75)=258,75 & \\
361.02 İşveren Primi (7,5+15)=22,5 & \\
Ayşe öğretmene hazırlık ödeneği tazminatı & \\
\hline
\end{tabular}

\subsection{Dönem Sonu İşlemleri}

Eğitim öğretim dönemi genellikle 30 Haziranda sona ermektedir. Bu tarihte özel okul işletmeleri yansıtma kayıtlarını kullanarak gider ve maliyet hesaplarını kapatacaktır. Gelir tablosu hesapları "690 Dönem Karı veya Zararı" hesabına aktarılacaktır. Bu hesabın borç kalını vermesi durumunda zarar ortaya çıkacaktır. Alacak kalanı vermesi durumunda ise kar ortaya çıkacak ve kurumlar vergisi hesaplanacaktır. Okulun dönem içerisinde ödemiş olduğu geçici vergi tutarının da kurumlar vergisinden mahsup edilmesi gerekecektir.

Örnek 8'de özel okullarda dönem sonu muhasebe işlemlerinin muhasebeleştirilmesi işlemlerine yer verilmiştir. Gelir ve gider hesaplarının “690 Dönem Karı veya Zararı” hesabına aktarıldığı varsayılmıştır.

Örnek 8: ABC Özel Okulu'na ait dönem sonu yansıtma kayıtları aşağıda verildiği gibidir. 690 nolu hesabın borç ve alacak toplamı aşağıda belirtildiği gibidir. Dönem içerisinde ödenen geçici vergi toplamı 912.000 TL'dir. Dönem sonunda yapılması gereken işlemleri muhasebeleştiriniz.

\begin{tabular}{|c|l|r|r|}
\hline 1 & \multicolumn{1}{|c|}{30.06 .2019} & \\
741 Hizmet Üretim Maliyeti Yansıtma Hesabı & 3.250 .000 & \\
761 Pazarlama Satış Dağıtım Giderleri Yansıtma Hesabı & 4.500 .000 \\
771 Genel Yönetim Giderleri Yansıtma Hesabı & 1.750 .000 \\
740 Hizmet Üretim Maliyeti & \\
760 Pazarlama Satı̧̧ Dağıtım Giderleri & 3.250 .000 \\
770 Genel Yönetim Giderleri & 4.500 .00 \\
& & 1.750 .000 \\
\hline
\end{tabular}




\begin{tabular}{|c|c|c|c|}
\hline 2 & 30.06 .2019 & & \\
\hline & 622 Satılan Hizmet Maliyeti & 3.250 .000 & \\
\hline & 631 Pazarlama Satış Dağıtım Giderleri & 4.500 .000 & \\
\hline & 632 Genel Yönetim Giderleri & 1.750 .000 & \\
\hline & 741 Hizmet Üretim Maliyeti Yansıtma Hesabı & & 3.250 .000 \\
\hline & 760 Pazarlama Satış Dağııım Giderleri Yansıtma Hesabı & & 4.500 .000 \\
\hline & 770 Genel Yönetim Giderleri Yansıtma Hesabı & & 1.750 .000 \\
\hline 3 & 30.06 .2019 & & \\
\hline & 690 Dönem Karı veya Zararı & 9.500 .000 & \\
\hline & 622 Satılan Hizmet Maliyeti & & 3.250 .000 \\
\hline & 631 Pazarlama Satış Dağıtım Giderleri & & 4.500 .000 \\
\hline & 632 Genel Yönetim Giderleri & & 1.750 .000 \\
\hline \multirow[t]{6}{*}{4} & 30.06 .2019 & & \\
\hline & 690 Dönem Karı veya Zararı & 2.950 .000 & \\
\hline & 611 Satış İskontoları & & 650.000 \\
\hline & 653 Komisyon Giderleri & & 710.000 \\
\hline & 654 Karşıllk Giderleri & & 770.000 \\
\hline & 656 Kambiyo Zararları & & 820.000 \\
\hline \multirow[t]{9}{*}{5} & 30.06 .2019 & & \\
\hline & 600 Yurt İçi Satışlar & 25.750 .000 & \\
\hline & 602 Diğer Gelirler & 4.475 .0000 & \\
\hline & 642 Faiz Gelirleri & 785.000 & \\
\hline & 644 Konusu Kalmayan Karş1lıklar & 650.000 & \\
\hline & 646 Kambiyo Karları & 710.0000 & \\
\hline & 649 Diğer Olağan Gelir ve Karlar & 720.0000 & \\
\hline & 671 Önceki Dönem Gelir ve Karları & 730.0000 & \\
\hline & 690 Dönem Karı veya Zararı & & 33.820 .000 \\
\hline
\end{tabular}

\begin{tabular}{|c|c|}
\hline \multicolumn{2}{|c|}{ 690 Karı veya Zararı } \\
\hline 12.450 .000 & 33.820 .000 \\
\hline
\end{tabular}

Ödenecek Kurumlar Vergisi $=21.370 .000 * 0,20=4.274 .000$ TL

Verilenlere göre dönem içinde ödenen geçici vergi tutarı 912.000 TL'dir. Bu tutarın dönem sonunda düzenleyici hesaba aktarılması gerekmektedir. 
Eğitim Sektörü Muhasebe Uygulama Süreçleri: Özel Okul Örneği

\begin{tabular}{|c|c|r|r|}
\hline 1 & \multicolumn{1}{|c|}{30.06 .2019} & $912.000,00$ & \\
$\begin{array}{l}371 \text { Dönem Karının Peşin Ödenen Vergi ve Diğer Yükümlülükleri } \\
193 \text { Peşin Ödenen Vergi ve Fonlar } \\
193.01 \text { Geçici Vergi }\end{array}$ & $912.000,00$ \\
$\begin{array}{l}\text { Dönem içinde peşin ödenen verginin dönem sonunda düzenleyici } \\
\text { hesaba aktarılmasi }\end{array}$ & \\
\hline
\end{tabular}

Kurumlar vergisi için dönem sonunda yapılması gereken işlemler aşağıdaki gibi olacaktır.

\begin{tabular}{|c|c|c|c|}
\hline 1 & $\begin{array}{l}30.06 .2019 \\
690 \text { Dönem Karı veya Zararı } \\
691 \text { Dönem Karı Vergi ve Diğer Yasal Yükümlülük Karşılığı } \\
692 \text { Dönem Net Karı veya Zararı }\end{array}$ & $21.370 .000,00$ & $\begin{array}{r}4.274 .000,00 \\
17.096 .000,00\end{array}$ \\
\hline 2 & $\begin{array}{l}\text { 30.06.2019 } \\
\text { 691 Dönem Karı Vergi ve Diğer Yasal Yükümlülük Karşılığı } \\
370 \text { Dönem Karı Vergi Diğer Yasal Yükümlülük Karşılıkları } \\
\text { Kurumlar vergisi karşılığı ayrılması }\end{array}$ & $4.274 .000,00$ & $4.274 .000,00$ \\
\hline 3 & $\begin{array}{l}\text { 30.06.2019 } \\
692 \text { Dönem Net Karı veya Zararı } \\
590 \text { Dönem Net Karı } \\
\text { Dönem net karının bilançoya aktarılması }\end{array}$ & 17.096.000,00 & $17.096 .000,00$ \\
\hline
\end{tabular}

Nisan, Mayıs ve Haziran aylarını kapsayan dördüncü dönem geçici vergiye dair kayıt ve ödemeler bir sonraki hesap dönemi olan Ağustos ayını kapsayacaktır. Dördüncü dönem geçici vergi ödeme dönemi geldiğinde yapılması gereken kayıt ve kurumlar vergisinin tahakkuk kaydı aşağıdaki şekilde olacaktır.

\begin{tabular}{|l|l|l|l|}
\hline 1 & \multicolumn{1}{|c|}{14.08 .2019} & $3.362 .000,00$ & \\
& $\begin{array}{l}370 \text { Dönem Karı Vergi Diğer Yasal Yükümlülük Karşılığı } \\
360 \text { Ödenecek Vergi ve Fonlar } \\
\text { Geçici Verginin Tahakkuku }\end{array}$ & $3.362 .000,00$ \\
\hline 2 & $\begin{array}{l}\text { 14.08.2019 } \\
370 \text { Dönem Karı Vergi Diğer Yasal Yükümlülük Karşılığı } \\
\text { 371 Dönem Karının Peşin Ödenen Vergi ve Diğer Yasal } \\
\text { Yükümlülükleri }\end{array}$ & $4.274 .000,00$ & \\
\hline
\end{tabular}




\begin{tabular}{|l|l|l|l|}
\hline & Kurumlar vergisinin tahakkuku & & \\
\hline 3 & $\begin{array}{l}\text { 14.08.2019 } \\
\begin{array}{l}\text { Ödenecek Vergi ve Fonlar } \\
102 \text { Bankalar } \\
\text { Geçici Verginin Ödenme kaydi }\end{array}\end{array}$ & $3.362 .000,00$ & $3.362 .000,00$ \\
\hline
\end{tabular}

\section{SONUÇLAR}

Özel eğitim kurumu olan ABC Özel Okulu yürütmüş olduğu faaliyetler dolayısıyla hizmet işletmesi kategorisinde yer almaktadır. $\mathrm{Bu}$ sebeple yürütmüş oldukları faaliyetlerin muhasebeleştirilmesinde hizmet üretim işletmelerindeki muhasebe akış süreci izlenmektedir.

Özel eğitim kurumlarının diğer hizmet üretim işletmelerinden ayrılan bir takım özellikleri mevcuttur. Faaliyete başladıkları dönem, geçici vergi ödeme durumları, personel giderleri, eğitim indirimi, ödenen okul ücretinin kredili olarak tahsili ve bedelsiz okutulan öğrencilerin KDV açısından durumları diğer işletmelerden ayrılan noktalardır. ABC Özel Okulları'nın hesap dönemi 1 Temmuzda başlarken 30 Haziranda sona ermektedir. Dolayısıyla okulun geçici vergi ödeme dönemleri de özel hesap dönemlerine göre belirlenmektedir. ABC Özel Okulu mizandan giderek geçici gelir tablosunu hazırlamakta ve envanter çalışmalarını da çalışma kağıtlarında göstermektedir. Gelir tablosu yardımıyla ticari kar hesaplanır. Ticari kara kanunen kabul edilmeyen giderler eklenerek geçici vergi matrahına ulaşılmaktadır. Ayrıca okulun daha önceki dönemde ödemiş olduğu geçici vergiler de mahsup edilmektedir. Personel giderleri açısından 2003 yılında değiştirilen genelgeyle birlikte devlet okullarında çalışan öğretmenlere uygulanan ücret istisnaların özel okullarda istihdam edilen öğretmenlere de uygulanacağı belirtilmiştir. Dolayısıyla ABC Özel Okulları'nda öğretmenlere ödenen eğitim tazminatı ve hizmet ödeneği hesaplanması ve bunların kayıt altına alınması ilgili yönetmelikler dikkate alınarak yapılmaktadır. ABC Özel Okulları öğrenci kaydı yaparken erken kayıt indirimi, iki kardeş indirimi gibi eğitim indirimi imkânları da tanımaktadır. Okul öncelikle hizmet satış kaydını "120 Alıcılar" hesabı ve "600 Yurt İçi Satışlar" hesabını kullanarak yapmaktadır. Daha sonra eğitim indirimini "611 Satış İndirimi" hesabı ve "120 Alıcılar" hesabını kullanarak kayıt altına almaktadır. Öğrencilerin eğitim ücretinin kredi kartı ile tahsilinde ise "108 Diğer Hazır Değerler" hesab1 kullanılmaktadır. Eğer tahsilat yine kredi kartıyla fakat taksitli olarak yapılacaksa "127 Ticari Alacaklar" hesabı kullanılması gerekecektir. Son olarak KDV kanunu açısından ABC Özel Okulları'nda bedelsiz okutulan öğrenci durumu ele alınmıştır. KDV kanununa göre kapasitenin \%10'na kadar bedelsiz okutulan öğrenciler KDV'den istisna tutulmuştur. Kapasitenin \%10'unu aşan sayıda bedelsiz okutulan öğrenciler için hesaplanan KDV kanunen kabul edilmeyen gider olarak kabul edilmektedir.

\section{KAYNAKLAR}

213 sayıl1 Vergi Usul Kanunu İç Genelgesi, B.07.1.GİB.4.46.15.01-B.07.1.GİB.4.46.15.0-2 (05 12, 2010).

Ağaya, S. (2012). Özel Öğretim Kurumlarında Muhasebe ve Vergilendirme Sistemi: Örnek Bir Uygulama. Erciyes Üniversitesi Sosyal Bilimler Enstitüsü. 
Ateş, K. (2016). İleri Düzey Muhasebe Rehberi. Ankara: Özbaran Ofset Matbacılık.

Gelir Vergisi Kanunu, 193 (12 31, 1960).

Gelir Vergisi Kanunu İç Genelgesi, B.07.0.GEL.0.42/4234-20/016250 (Maliye Bakanlığı 04 15, 2003).

Kabaca, B. (2019, 04 23). Özel Okullarda Vergi Uygulamaları. https://docplayer.biz.tr/13592793Ozel-okullarda-vergi-uygulamalari.html

Kurumlar Vergisi Kanunu, $5520(06$ 13, 2006).

Milli Eğitim Temel Kanunu, 1739 (06 14, 1973).

Müdürlüğ̈̈, [. B. (2019, 04 22). İstatistikler. https://www.bumko.gov.tr/TR,909/maas-istatistikleri-verileri.html

Öz, E., \& Buyrukoğlu, S. (2011). Türk Eğitim sisteminde Vergileme: Denizli İlinde Bİr Uygulama. Sosyo Ekonomi, 75-100.

Özel Öğretim Kurumları Kanunu, 5580 (02 14, 2007).

Vergi Usul Kanunu, 213 (01 04, 1961). 